\title{
CROSSFIT TRAININGS AS AN ALTERNATIVE APPROACH TO PREVENT THE PERFORMANCE LOSS DURING THE REST OF THE END OF SEASON IN ELITE WRESTLERS
}

\author{
S. Özbay', serhat.ozbay@erzurum.edu.tr, ORCiD: 0000-0001-6424-8871, \\ T. Akbulut ${ }^{2}$, akbuluttaner23@gmail.com, ORCiD: 0000-0003-2500-1117, \\ V.Cinar', cinarvedat@hotmail.com, ORCiD: 0000-0003-4883-3995 \\ ${ }^{1}$ Erzurum Technical University, Erzurum, Turkey, \\ ${ }^{2}$ Firat University, Elazig, Turkey
}

\begin{abstract}
Aim. The objective of this study is to investigate the effectiveness of Crossfit training in order to minimize performance loss of elite wrestlers during 30-day rest period. Materials and Methods. Total 23 elite male wrestlers who competed at the last national championship participated in this study. The participants were divided into two groups as Crossfit and control group. The Crossfit group performed 5 pull-ups, 10 push-ups and 15 squat exercises consecutively (Crossfit-Cindy) for total 20-min, during the 30-day period, 6 days per week. The Control group did not perform any exercise programs during this period. Before and after the 30-day period, athletes were applied anthropometric measurements as well as $\mathrm{VO}_{2} \max$ (aerobic capacity), bench press and squat (maximal dynamic strength), leg and handgrip strength (isometric strength), pull-up and push-up (strength endurance) tests. Results. After the 30-day period in the control group, body weight and body fat percentage (BF \%) increased significantly, whereas all performance variables decreased significantly. Maximal dynamic strength and aerobic capacity values decreased significantly in the Crossfit group, while body weight, body fat percentage, isometric strength and strength endurance values were maintained. Moreover, the decrease in $\mathrm{VO}_{2} \max$ and bench press tests was higher in the control group than in the Crossfit group. Conclusion: Consequently, the present study showed that 20-min Crossfit training was highly effective in maintaining the form of elite wrestlers during a 30-day rest period.
\end{abstract}

Keywords: Wrestling, CrossFit, Strength, isometric force.

\section{Introduction}

Crossfit training is a general strength and fitness program that comprise of high intensity strength exercises [12]. Crossfit trainings aim to create the great metabolic demands by performing the exercises fast, repetitive and with limited or no rest between sets [4]. It has gained great popularity recently due to its short duration and effectiveness $[4,8,25]$. There are studies showing the effectiveness of a large number of Crossfit programs involving different exercises, set, repetition, and rest intervals [25, 29]. Some Crossfit programs seem to be useful exercise programs due to the fact that they contain callisthenic exercises and are easily applicable and accessible $[8,29]$. Crossfit has been mostly preferred by recreational athletes to date, however future studies are needed to determine whether their impact on professional athletes is sufficient $[12,25]$.

Male wrestling is an Olympic event that has presented a competition consisting power and combat in the modern Olympic Games since 1896 Athens. Currently, Greco-Roman and freestyle are the two internationally recognized forms of competitive male wrestling by Federation Internationale de Lutte Association (FILA). According to FILA rules, during a Greco-Roman wrestling, athletes only can attack and use their upper body and, holds below the waist are forbidden, whereas during a freestyle wrestling, they can use their whole body. Male wrestling consists of great strength and muscle power demands on both the upper and lower body, with intermittent and high-intensity effort requirements in both styles. The main goal of wrestlers is to physically dominate the opponent and to establish physical control over him [5]. Wrestling requires high levels of physical and physiological profile consisting strength, power, agility, flexibility, and endurance [27]. Physical characteristics such as maximal dynamic strength, isometric strength, explosive strength, and strength endurance are selective factors top-level wrestling performance $[5,10,23,24]$. Furthermore strength is an important component for performance. Strength training affects some parameters that related to health as well as performance $[6,7]$.

Wrestling competition calendar are carried 


\section{Спортивная тренировка}

out periodically and spread over an entire year. In addition, the wrestlers have a rest period of 30-45 days following the competition season. It is clear that short-term and effective exercise programs can be very useful for wrestlers to maintain their forms in resting period which is longer compared to other sports branches. However, the literature is void in wrestlers about the loss of performance after rest periods and prevention of this. Therefore, the aim of this study was to determine the change in performance following a rest period of 30 days and to investigate the effect of Crossfit training on this change in elite wrestlers.

\section{Materials and Methods}

Participants. Twenty-three elite male wrestlers (12 experimental group and 11 control group) participated in this study. The inclusion criteria of the participants is to train regularly for at least 5 years and actively participating in national and international competitions. Patients with current orthopedic or health disorder were not included in the study. Participants, their families and coaches were informed about study design, and they were obtained written informed consent to participate this study. The present study was conducted in accordance with the Helsinki Declaration. The descriptive characteristics of the participants were presented in Table 1.

Anthropometric measurements. The height of the participants were measured by stadiometer (Holtain Ltd., UK); weight, body mass index (BMI) and body fat percentage (BF \%) were measured by bioelectrical impedance analyzer (Tanita TBF 401, Japan).
Aerobic capacity test. Yo-Yo intermittent recovery test (Level 1) was used to determine the $\mathrm{VO}_{2}$ max levels of athletes. This test consisted of $20 \mathrm{~m}$ shuttle runs performed at increasing velocities with $10 \mathrm{~s}$ of active recovery (consisting of $2 \times 5 \mathrm{~m}$ of jogging) between runs until exhaustion. The test started at a speed of $10 \mathrm{~km} \cdot \mathrm{h}^{-1}$ and, it continues to increase with stepwise until exhaustion $[19,20]$. The speed was controlled by audio beeps from mobile application. When the participants failed twice to reach the finishing line in time, test was ended, and the covered distance was recorded as the valid score and calculated following formula [3].

$\mathrm{VO}_{2} \max \left(\mathrm{ml} \cdot \mathrm{kg}^{-1} \cdot \mathrm{min}^{-1}\right)=$

$=$ distance $(\mathrm{m}) \times 0,0084+36,4$.

Strength Tests. Maximal dynamic strength of participants were measured maximum using one repetition squat and bench press test. The participants performed a standart warming up consisting of 10 repetitions at $50 \%$ of the squat and bench press loads. The wrestlers performed 3 trial for both test at 5-min intervals. The load was increased by $3-10 \%$ in valid trials or reduced by $3-10 \%$ in invalid trials according to the request of the participants. For a trial to be considered a valid repetition, it was based on completing a full range of motion and returning to the starting position. Results were recorded in the lifted maximum relative load (lifted load $\mathrm{kg} \times$ body mass $\mathrm{kg}^{-1}$ ).

Isometric strengths of participants were measured via relevant dynamometers (Takei A5001 Hand Grip Dynamometer and Takei A5002 Leg Dynamometer, Tokyo, Japan). Dominant hand

Table 1

Descriptive and performance characteristics

\begin{tabular}{lcccc}
\hline & Crossfit & Control & $\mathrm{t}$ & $\mathrm{p}$ \\
\hline Age (year) & $20.4 \pm 1.7$ & $19.4 \pm 1.9$ & 1.429 & 0.168 \\
Height (cm) & $168.8 \pm 9.8$ & $169.7 \pm 9.7$ & 0.240 & 0.813 \\
Weight (kg) & $70.7 \pm 10.1$ & $65.9 \pm 9.8$ & 1.136 & 0.269 \\
Fat \% & $10.4 \pm 3.1$ & $10.7 \pm 2.8$ & 0.275 & 0.786 \\
$\mathrm{VO}_{2} \mathrm{max}(\mathrm{ml} \mathrm{/} \mathrm{kg-1})$ & $53.5 \pm 4.6$ & $52.7 \pm 3.3$ & 0.483 & 0.634 \\
$\mathrm{BP}\left(\mathrm{kg}^{-1}\right)$ & $1.2 \pm 0.1$ & $1.2 \pm 0.1$ & 0.929 & 0.363 \\
$\mathrm{SQ}\left(\mathrm{kg}^{-1}\right)$ & $1.5 \pm 0.2$ & $1.5 \pm 0.2$ & 0.560 & 0.581 \\
LS (kg-1) & $2.7 \pm 0.3$ & $2.6 \pm 0.3$ & 0.841 & 0.410 \\
$\mathrm{HGS}\left(\mathrm{kg}^{-1}\right)$ & $0.7 \pm 0.2$ & $0.7 \pm 0.1$ & 0.401 & 0.692 \\
Push-up (repetition) & $36.5 \pm 7.6$ & $39.7 \pm 5.8$ & 1.135 & 0.269 \\
Pull-up (repetition) & $77.2 \pm 8$ & $80.4 \pm 9.7$ & 0.863 & 0.398 \\
\hline
\end{tabular}

Values were presented mean $\pm \mathrm{SD}$.

$\mathrm{BP}, \mathrm{SQ}, \mathrm{LS}$, and HGS values were presented relatively (body mass. $\mathrm{kg}^{-1}$ ).

$\mathrm{BP}=$ bench press; $\mathrm{SQ}=$ squat; LS = leg strength; HGS = handgrip strength. 
Participants' performance values before and after the 30-day period

Table 2

\begin{tabular}{|c|c|c|c|c|c|c|}
\hline & \multicolumn{2}{|c|}{ Crossfit } & \multicolumn{4}{|c|}{ Control } \\
\hline & Before & After & Change & Before & After & Change \\
\hline Weight (kg) & $70.68 \pm 10.14$ & $71.19 \pm 10.12$ & $\begin{array}{c}1 \% \\
\text { increase }\end{array}$ & $65.9 \pm 9.83$ & $67.6 \pm 9.51^{*}$ & $\begin{array}{c}2.6 \% \\
\text { increase }\end{array}$ \\
\hline Fat $\%$ & $10.36 \pm 3.09$ & $10.45 \pm 3.11$ & $\begin{array}{c}1 \% \\
\text { increase }\end{array}$ & $10.70 \pm 2.84$ & $11.4 \pm 2.92 *^{\#}$ & $\begin{array}{c}6.5 \% \\
\text { increase }\end{array}$ \\
\hline $\begin{array}{l}\mathrm{VO}_{2} \max \\
\left(\mathrm{ml} / \mathrm{kg}^{-1}\right)\end{array}$ & $53.48 \pm 4.60$ & $52.45 \pm 4.67^{*}$ & $\begin{array}{c}2 \% \\
\text { decrease }\end{array}$ & $52.67 \pm 3.27$ & $48.85 \pm 3.33^{* \#}$ & $\begin{array}{c}7.8 \% \\
\text { decrease }\end{array}$ \\
\hline $\mathrm{BP}\left(\mathrm{kg}^{-1}\right)$ & $1.19 \pm 0.11$ & $1.15 \pm 0.10^{*}$ & $\begin{array}{c}3.5 \% \\
\text { decrease }\end{array}$ & $1.23 \pm 0.14$ & $1.12 \pm 0.17 *^{\#}$ & $\begin{array}{c}10 \% \\
\text { decrease }\end{array}$ \\
\hline $\mathrm{SQ}\left(\mathrm{kg}^{-1}\right)$ & $1.57 \pm 0.15$ & $1.48 \pm 0.17^{*}$ & $\begin{array}{c}6 \% \\
\text { decrease }\end{array}$ & $1.48 \pm 0.17$ & $1.41 \pm 0.13^{*}$ & $\begin{array}{c}5.4 \% \\
\text { decrease }\end{array}$ \\
\hline $\mathrm{LS}\left(\mathrm{kg}^{-1}\right)$ & $2.67 \pm 0.33$ & $2.62 \pm 0.38$ & $\begin{array}{c}2 \% \\
\text { decrease }\end{array}$ & $2.56 \pm 0.29$ & $2.41 \pm 0.31^{* \#}$ & $\begin{array}{c}6 \% \\
\text { decrease }\end{array}$ \\
\hline $\operatorname{HGS}\left(\mathrm{kg}^{-1}\right)$ & $0.67 \pm 0.18$ & $0.66 \pm 0.17$ & $\begin{array}{c}1 \% \\
\text { decrease }\end{array}$ & $0.7 \pm 0.14$ & $0.65 \pm 0.12^{* \#}$ & $\begin{array}{c}7 \% \\
\text { decrease }\end{array}$ \\
\hline $\begin{array}{l}\text { push-up } \\
\text { (repetition) }\end{array}$ & $36.50 \pm 7.62$ & $36.25 \pm 7.57$ & $\begin{array}{c}0.6 \% \\
\text { decrease }\end{array}$ & $39.72 \pm 5.79$ & $34.81 \pm 5.04^{* \#}$ & $\begin{array}{c}14 \% \\
\text { decrease }\end{array}$ \\
\hline $\begin{array}{l}\text { pull-up } \\
\text { (repetition) }\end{array}$ & $77.16 \pm 7.99$ & $76.16 \pm 8.86$ & $\begin{array}{c}1.4 \% \\
\text { decrease }\end{array}$ & $80.36 \pm 9.75$ & $72.63 \pm 9.06^{* \#}$ & $\begin{array}{c}10 \% \\
\text { decrease }\end{array}$ \\
\hline
\end{tabular}

Values are presented mean $\pm \mathrm{SD}$.

BP, SQ, LS, and HGS values were presented relatively (body mass. $\mathrm{kg}^{-1}$ ).

*There is significant difference between before and after values.

${ }^{\#}$ Group X time (before-after) interaction is significant, at $\mathrm{p}<0.05$.

$\mathrm{BP}=$ bench press; $\mathrm{SQ}=$ squat $\mathrm{LS}=$ leg strength; HGS = handgrip strength.

was preferred during the hand grip strength test. Results were recorded in the maximum relative strength (absolute strength $\times$ body mass $\mathrm{kg}^{-1}$ ). During the leg strength test, the pull-bar of the dynamometer was placed in the hands and the angle of the knees was set at $45^{\circ}$ angle. In both tests, the highest score from two trials with 3-min rest intervals was considered valid $[10,17]$.

Strength endurance performances of participants were determined via pull-up and push-up tests. During the tests, a metronome was used to control the tempo of the exercises, and the participants were not allowed to rest more than one second in the top or down position. To be valid the pull-up test, the total number of repetitions the participant was able to pull the chin above the constant bar were calculated. To be valid the push-up test, the total number of repetitions the participant was able to complete full range of motion and to return to the starting position were calculated.

Statistical Analysis. Statistical analyzes were performed using SPSS 21.0 program. Significance level was accepted as $p<0.05$. Mean and standard deviation were used for data analysis. Independent t-test was used to determine whether there was any difference between the groups at the beginning of the study. Paired t-test was used to determine the difference between the values of a group before and after the research period. In addition, two-way ANOVA test was used for repeated measurements to determine the group $\mathrm{X}$ time (pre-post) interactions.

There was no difference between the groups in terms of descriptive or performance variables before the 30-day period (Table 2).

\section{Results}

Significant decrease was observed in all performance variables as well as body weight and fat percentage (BF \%) in the control group. Significant decreases in maximal dynamic strength variables (BP and SQ) and aerobic capacity $\left(\mathrm{VO}_{2} \mathrm{max}\right)$ were observed in the Crossfit training group, but there was no significant difference in isometric strength (LS and HGS) and strength endurance (pull-up and push up).

\section{Discussion}

In sports, especially in wrestling, due to the high number of international tournaments before big championships, performance control is an issue that has gained importance in recent years. Testing the training methods and programs used periodically is an important factor in monitoring performance improvement [2]. Especially 


\section{Спортивная тренировка}

after this intense pace, athletes spend up to a period of 3 weeks and sometimes longer at the end of the season without training. Starting the next season with minimal performance decrease is vital for elite athletes in an environment where competition intensity and competition is so high. In our study; at the end of the 30-day non-training period of the control group, body weight and body fat percentage increased significantly and all performance variables decreased significantly. In the CrossFit group, maximal dynamic strength and aerobic capacity decreased significantly; while body weight, body fat percentage, isometric strength and all-out strength endurance values were maintained. In addition, the decreases in fat $\%(6.5 \%$ vs $1 \%), \mathrm{VO}_{2} \max (7.8 \%$ vs $2 \%)$, BP (10\% vs $3.5 \%)$, HGS (7 \% vs $1 \%$ ), LS (6\% vs $2 \%$ ), push-up (14\% vs $0.6 \%$ ) and pull-up ( $10 \%$ vs $1.4 \%$ ) variables were higher in the control group than in the CrossFit group.

Wrestling is defined as a sport in which anaerobic energy system is used predominantly and factors such as speed, strength, quickness, flexibility, balance, muscular and cardiovascular endurance and coordination affect performance $[1,2,13,21]$. A great number of articles have been published about the physical and physiological characteristics of wrestlers $[5,9,15,28]$. However, in terms of a research design similar to our study, literature is void. It is known that wrestling is associated with the overload of muscles and joints, especially shoulders, trunk and hips, and is one of the high intensity combat sports [11]. Therefore, power and performance improvements are needed to prevent injury and improve performance [22]. In addition, regardless of style, wrestling requires a maximum level of strength and force for explosive attacks during the competition [18]. Since they also have to cope with the rehabilitation process, wrestlers have to develop their injury prevention strategies. Strength training and fitness programs have an important place among these strategies [16]. Condition training programs including multiple and well-designed resistance training, plyometric training, personal training and balance training will certainly help to improve athletic performance.

Perhaps importantly, these exercises are very important in terms of raising awareness for avoiding common injuries, emphasizing practice with the right technique, minimizing the risk of injury and developing multiple metabolic systems [14]. Clearly the development of metabolic systems plays an important role in the success of wrestlers $[18,26]$. Due to the intensity of training in the wrestling branch and the fact that competition calendar is spread over the whole year, wrestlers need to maintain their performance at a certain level throughout the season in order to adequately meet the metabolic needs of these competitions and to avoid possible injury. Considering the yearlong intense training pace and intense competition processes, it is a fact that the wrestlers need psychological and physiological rest.

Conclusions. It is advisable for wrestlers to practice CrossFit training individually to maintain their sporting performance and to minimize performance decrease during transition phase in yearly training cycle. It is thought that CrossFit trainings can be preferred as an alternative approach in terms of ease of practice and giving freedom of time and space. According to the results of this study, performance loss was observed in wrestlers after passive resting phase. However, it was shown that wrestlers who spend this phase with CrossFit (Cindy) training method reduce performance loss to a lesser extent.

\section{References}

1. Akgün N. Exercise Physiology. Edition, 1986, vol. 1, pp. 60-198.

2. Alpay B., Hazar S. Comparison and Evaluation of Some Respiratory and Circulation Parameters of Turkish Wrestling National Team Athletes with Niğde University Wrestling Team Athletes. Journal of Physical Education and Sport Sciences, 2006, vol. 8, no. 3, pp. 25-33.

3. Bangsbo J., Iaia F.M., Krustrup P. The Yo-Yo Intermittent Recovery Test. Sports medicine, 2008, vol. 38, no. 1, pp. 37-51. DOI: 10.2165/00007256-200838010-00004

4. Butcher S.J., Neyedly T.J., Horvey K.J., Benko C.R. Do Physiological Measures Predict Selected Crossfit Benchmark Performance? Open Access Journal of Sports Medicine, 2015, vol. 6, pp. 241-247. DOI: 10.2147/OAJSM.S88265

5. Chaabene H., Negra Y., Bouguezzi R., Mkaouer B., Franchini E., Julio U., Hachana Y. Physical and Physiological Attributes of Wrestlers: an Update. The Journal of Strength \& Conditioning Research, 2017, vol. 31, no. 5, pp. 1411-1442. DOI: $10.1519 /$ JSC.0000000000001738

6. Cinar V., Akbulut T., Kilic Y., Özdal M., Sarikaya M. The Effect of 6-Week Zinc Supplement and Weight Training on the Blood Lipids of 
the Sedentaries and Athletes. Cell Mol Biol (Noisy le Grand), 2018, vol. 64, no. 11, pp. 1-5. DOI: $10.14715 / \mathrm{cmb} / 2018.64 .11 .1$

7. Çinar V., Talaghir L.G., Akbulut T., Turgut M., Sarikaya M. The Effects of the Zinc Supplementation and Weight Trainings on the Testosterone Levels. Human. Sport. Medicine, 2017, vol. 17, no. 4, pp. 58-63. DOI: 10.14529/hsm 170407

8. Claudino J.G., Gabbett T.J., Bourgeois F., de Sá Souza H., Miranda R. C., Mezêncio B., Hernandez A.J. Crossfit Overview: Systematic Review and Meta-Analysis. Sports MedicineOpen, 2018, vol. 4, no. 4, pp. 1-14. DOI: 10.1186/s40798-018-0124-5

9. Demirel N., Özbay S., Kaya F., Bayram M. The Effects of Aerobic and Anaerobic Training Programs Applied to Elite Wrestlers on Body Composition. International Journal of Social Sciences and Education Research, 2017, vol. 3, no. 2, pp. 675-682. DOI: 10.24289/ijsser.288803

10. Demirkan E., Koz M., Kutlu M., Favre M. Comparison of Physical and Physiological Profiles in Elite and Amateur Young Wrestlers. The Journal Of Strength \& Conditioning Research, 2015, vol. 29, no. 7, pp. 1876-1883. DOI: $10.1519 /$ JSC.0000000000000833

11. Franchini E., Panissa V.L., Julio U.F. Physiological and Performance Responses to Intermittent Uchi-Komi in Judo. The Journal of Strength \& Conditioning Research, 2013, vol. 27, no. 4, pp. 1147-1155. DOI: 10.1519/JSC.0b013e3182606d27

12. Glassman G. Understanding Crossfit. CrossFit Journal, 2007, vol. 56, no. 1, pp. 1-2.

13. Gökdemir K. Scientific Basis of Wrestling Training. Poyraz offset, 2000, 15 p.

14. Grindstaff T.L., Potach D.H. Prevention of Common Wrestling Injuries. Strength \& Conditioning Journal, 2006, vol. 28, no. 4, pp. 20-28. DOI: 10.1519/00126548-200608000-00002

15. Horswill C.A. Applied Physiology of Amateur Wrestling. Sports Medicine, 1992, vol. 14, no. 2, pp. 114-143. DOI: 10.2165/ 00007256-199214020-00004

16. İnce, İ. Effects of Split Style Olympic Weightlifting Training on Leg Stiffness Vertical Jump Change of Direction and Sprint in Collegiate Volleyball Players. Universal Journal of Educational Research, 2019, vol. 7, no. 1, pp. 24-31. DOI: 10.13189/ujer.2019.070104

17. Itaka T., Agemizu K., Aruga S., Machida S.G. Allele of the IGF2 Apai Polymorphism is Associated with Judo Status. The Jour- nal of Strength \& conditioning research, 2016, vol. 30, no. 7, pp. 2043-2048. DOI: 10.1519/JSC.0000000000001300

18. Kraemer W.J., Fry A.C., Rubin M.R., Triplett-McBride T., Gordon S.E., Koziris L.P., Fleck S.J. Physiological and Performance Responses to Tournament Wrestling. Medicine and Science in Sports and Exercise, 2001, vol. 33, no. 8, pp. 1367-1378. DOI: 10.1097/00005768200108000-00019

19. Krustrup P., Mohr M., Amstrup T., Rysgaard T., Johansen J., Steensberg A., Bangsbo J. The Yo-Yo Intermittent Recovery Test: Physiological Response, Reliability, and Validity. Medicine \& Science in Sports \& Exercise, 2003, vol. 35, no. 4, pp. 697-705. DOI: 10.1249/01.MSS.0000058441.94520.32

20. Krustrup P., Mohr M., Nybo L., Jensen J.M., Nielsen J.J., Bangsbo J. The Yo-Yo IR2 Test: Physiological Response, Reliability, and Application to Elite Soccer. Medicine \& Science in Sports \& Exercise, 2006, vol. 38, no. 9, pp. 1666-1673. DOI: 10.1249/01.mss.000022 7538.20799 .08

21. MacDougall J.D., Wenger H.A., Green H.J. Physiological Testing of the HighPerformance Athlete. Medicine \& Science in Sports \& Exercise, 1993, vol. 25, no. 2, pp. 305. DOI: 10.1249/00005768-199302000-00027

22. Marques V., Coswig V., Viana R., Leal A., Alves F., Alves A., Gentil P. Physical Fitness and Anthropometric Measures of Young Brazilian Judo and Wrestling Athletes and Its Relations to Cardiorespiratory Fitness. Sports, 2019, vol. 7, no. 2, pp. 38. DOI: 10.3390/sports7020038

23. Mirzaei B., Curby D.G., RahmaniNia F., Moghadasi M. Physiological Profile of Elite Iranian Junior Freestyle Wrestlers. The Journal of Strength \& Conditioning Research, 2009, vol. 23, no. 8, pp. 2339-2344. DOI: 10.1519/JSC.0b013e3181bb7350

24. Roemmich J.N., Frappier J.P. Physiological Determinants of Wrestling Success in High School Athletes. Pediatric Exercise Science, 1993, vol. 5, no. 2, pp. 134-144. DOI: 10.1123/pes.5.2.134

25. Smith M.M., Sommer A.J., Starkoff B.E., Devor S.T. Crossfit-Based High-Intensity Power Training Improves Maximal Aerobic Fitness and Body Composition. J Strength Cond Res, 2013, vol. 27 , no. 11 , pp. 3159-3172. DOI: 10.1519/JSC.0b013e318289e59f 


\title{
Спортивная тренировка
}

26. Utter A.C., O'Bryant H.S., Haff G.G., Trone G.A. Physiological Profile of an Elite Freestyle Wrestler Preparing for Competition: a Case Study. The Journal of Strength \& Conditioning Research, 2002, vol. 16, no. 2, pp. 308-315. DOI: 10.1097/00005768-200205001-01784

27. Yamashita D., Arakawa H., Arimitsu T., Wada T., Yumoto K., Fujiyama K., Shimizu S. Physiological Profiles of International-and Collegiate-Level Japanese Male Freestyle Wrestlers in the Lightweight Classes. International Journal of
Wrestling Science, 2017, vol. 7, no. 1-2, pp. 21-25. DOI: 10.1080/21615667.2017.1341572

28. Yoon J. Physiological Profiles of Elite Senior Wrestlers. Sports Medicine, 2002, vol. 32, no. 4, pp. 225-233. DOI: 10.2165/00007256200232040-00002

29. Yüksel O., Gündüz B., Kayhan M. Effect of Crossfit Training on Jump and Strength. Journal of Education and Training Studies, 2019, vol. 7, no. 1, pp. 121-124. DOI: 10.11114/jets.v7i1.3896

Received 15 October 2019

\section{КРОССФИТ КАК АЛЬТЕРНАТИВНЫЙ ПОДХОД К ПРЕДОТВРАЩЕНИЮ СНИЖЕНИЯ ПРОИЗВОДИТЕЛЬНОСТИ У ПРОФЕССИОНАЛЬНЫХ БОРЦОВ В КОНЦЕ СЕЗОНА}

\author{
С. Ёзбай ${ }^{1}$, T. Акбулут ${ }^{2}$ В. Джинар ${ }^{2}$ \\ ${ }^{1} Э$ рзурумский технический университет, е. Эрзурум, Турция, \\ ${ }^{2}$ Университет Фирата, е. Элязыг, Турция
}

\begin{abstract}
Цель: оценить эффективность кроссфит-тренировок, чтобы снизить потерю производительности элитных борцов во время тридцатидневного отдыха. Материалы и методы. В исследовании принимали участие 23 элитных спортсмена, выступавших на прошлом национальном чемпионате. Все участники были поделены на две группы - контрольная группа и группа, практиковавшая занятия по системе кроссфит. Кроссфит-группа последовательно выполняла 5 подтягиваний, 10 отжиманий и 15 приседаний на протяжении 20 минут в течение 30 дней 6 раз в неделю (Кроссфит Синди). Контрольная группа не выполняла никаких упражнений в период отдыха. До и после тридцатидневного отдыха были измерены антропометрические показатели и максимальное потребление кислорода (аэробные возможности), а также проведены тестирования для упражнений «жим лежа» и «приседания» (максимальная динамическая сила), измерены сила ног и сила захвата (изометрическая сила), проведен тест на выполнение подтягиваний и отжиманий (силовая выносливость). Результаты. Через 30 дней в контрольной группе масса тела и процент содержания жира (BF \%) значительно возросли, в то время как все показатели производительности значительно снизились. Максимальная динамическая сила и аэробные возможности значительно сократились в кроссфит-группе, при этом масса тела, процент содержания жира в организме, изометрическая сила и силовая выносливость остались неизменными. Более того, сокращение показателей максимального потребления кислорода и ухудшение результатов теста на выполнение упражнения «жим лёжа» были выше в контрольной группе. Заключение. Настоящее исследование показало, что двадцатиминутный комплекс кроссфит-упражнений эффективен для поддержания формы у элитных спортсменов во время тридцатидневного отдыха.
\end{abstract}

Ключевые слова: реслинг, CrossFit, кроссфит, сила, изометрическая сила. 
Ёзбай Серхат, $\mathrm{PhD}$, кафедра физического воспитания и спорта, факультет спортивных наук, Эрзурумский Технический Университет, г. Эрзурум, Турция. E-mail: serhat.ozbay@erzurum.edu.tr, ORCID: 0000-0001-6424-8871.

Акбулут Танер, $\mathrm{PhD}$, кафедра подготовки тренеров, факультет спортивных наук, Университет Фират, г. Элязыг, Турция. E-mail: akbuluttaner23@gmail.com, ORCID: 0000-0003-2500-1117.

Джинар Ведат, $\mathrm{PhD}$, кафедра физического воспитания и спорта, факультет спортивных наук, Университет Фират, г. Элязыг, Турция. E-mail: cinarvedat@hotmail.com, ORCID: 0000-0003-4883-3995.

Поступила в редакцию 15 октября 20192.

\section{ОБРАЗЕЦ ЦИТИРОВАНИЯ}

Özbay, S. Crossfit Trainings as an Alternative Approach to Prevent the Performance Loss During the Rest of the End of Season in Elite Wrestlers / S. Özbay, T. Akbulut, V. Cinar // Человек. Спорт. Медицина. - 2019. T. 19, № S2. - C. 51-57. DOI: 10.14529/hsm19s207

\section{FOR CITATION}

Özbay S., Akbulut T.,Cinar V. Crossfit Trainings as an Alternative Approach to Prevent the Performance Loss During the Rest of the End of Season in Elite Wrestlers. Human. Sport. Medicine, 2019, vol. 19, no. S2, pp. 51-57. DOI: $10.14529 / \mathrm{hsm} 19 \mathrm{~s} 207$ 